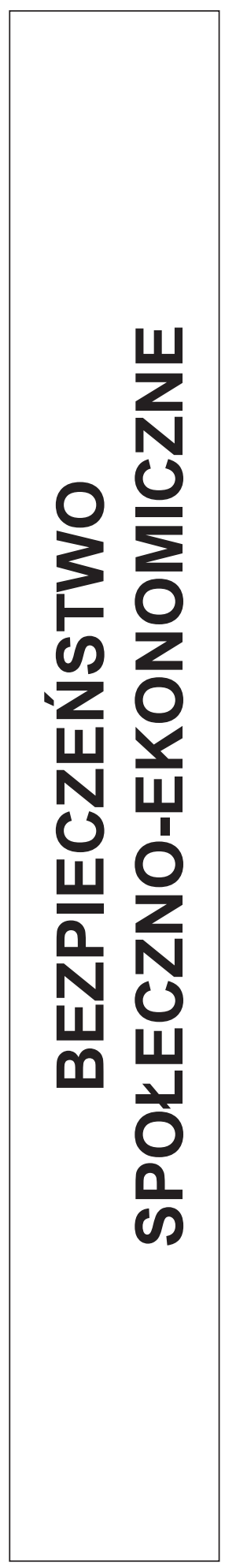





\section{Z POWROTEM DO DEBATY NEO-NEO. DWA SPOJRZENIA NA BEZPIECZEŃSTWO ENERGETYCZNE}

Teorie stosunków międzynarodowych nastawione są na poszukiwanie wzorów interakcji w polityce międzynarodowej i dostarczanie modeli eksplanacyjnych odnoszonych do struktury tychże interakcji. Ogólnie rzecz ujmując, teorie w sposób dorozumiany lub bezpośredni mówią o tym, jak polityka ta powinna być prowadzona, oczywiście w ramach określonego sposobu myślenia, paradygmatu, opierającego swe istnienie na krytyce alternatywnych spojrzeń teoretycznych. O tym, że jest ich niemało świadczy fakt, że obok tradycyjnego w nauce o stosunkach międzynarodowych podziału na (neo)realizm, (neo)liberalizm, oraz globalizm (teorie imperializmu, teoria zależności, teoria systemu światowego) stopniowo po zakończeniu zimnej wojny popularność zdobywają: konstruktywizm, teoria krytyczna, feministyczna, socjologia historyczna oraz poststrukturalizm. Zastanawiające jest jednak, że pomimo wielości szkół myślenia, bezpieczeństwo energetyczne stosunkowo rzadko analizowane jest w perspektywie teoretycznej. Znaczne możliwości w tym względzie daje badanie kryzysów energetycznych oraz konfliktów wywoływanych ograniczonym dostępem do energii i surowców naturalnych. Pomimo znacznego potencjału eksplanacyjnego tkwiącego w tej problematyce - aspekty teoretyczne bezpieczeństwa energetycznego poruszane są rzadko. Świadczy o tym fakt, że w jednym z najważniejszych międzynarodowych periodyków z zakresu bezpieczeństwa - „International Security” - teksty poświęcone energii opublikowano jedynie ośmiokrotnie w ciagu 30 lat (Liber, 1992: 155-176; Paarlberg, 1978: 3-19). Znacznie więcej artykułów w tym zakresie publikowanych jest w „Foreign Affairs”, „Foreign Policy”, „International Affairs” czy ,Washington Quarterly", jednakże w tych opiniotwórczych czasopismach najczęściej podkreśla się kwestie dotykające raczej sfery ontologicznej bezpieczeństwa energetycznego, kosztem zagadnień teoretycznych. Wydaje się zatem uzasadnione poświęcenie im miejsca, tym bardziej, że przedmiotowa materia jest złożona. Świadczą o tym odmienne zapatrywania na bezpieczeństwo energetyczne wyrażane z jednej strony przez organizacje międzynarodowe (np. IEA, ONZ, UE), pozarządowe i transnarodowe, z drugiej zaś strony, przez państwa. Organizacje zwracają przede wszystkim uwagę na jego aspekt pozytywny, przejawiający się w trzech kontekstach: 1) społecznym; 2) ekonomicznym; 3) środowiskowym. Z kolei państwa bezpieczeństwo energetyczne zaliczają do sfery żywotnych interesów. W odróżnieniu od neoliberalnego postrzegania bezpieczeństwa energetycznego przez organizacje i instytucje międzynarodowe jako: pozytywnego lub ludzkiego (human security), poszczególne państwa, optują raczej za neorealistycznym myśleniem ,zanurzonym” w narracji geopolitycznej, względnie geoekonomicznej. 
Mamy więc do czynienia z jeszcze jedną płaszczyzną klasycznej już debaty neo-neo. Celem niniejszego artykułu jest nie tylko ukazanie rozbieżności między ujęciem neorealistycznym a neoliberalnym w odniesieniu do problematyki bezpieczeństwa energetycznego, ale także zanalizowanie, w sposób właściwy wskazanym szkołom myślenia, współczesnych zjawisk i procesów wpływających na relacje między graczami na „energetycznej szachownicy”. Służą temu dwa studia przypadku, z których pierwszy poświęcono chińskiej strategii energetycznej na „Większym Bliskim Wschodzie” (neorealizm), drugi zaś - problemowi instytucjonalizacji polityki energetycznej Unii Europejskiej (neoliberalizm).

\section{(NEO)REALIZM I GEOPOLITYKA WOBEC BEZPIECZEŃSTWA ENERGETYCZNEGO}

Klasyczny, dominujący w połowie XX w., realizm zakładał, że istnieje zasadnicza różnica między polityką prowadzoną wewnątrz państwa i tą która jest prowadzona między państwami. Bierze się ona stąd, że w tym drugim przypadku brakuje niezależnego arbitra, władnego by stłumić dążenie do władzy i naturalne tendencje człowieka ku agresji. Wskazywali na to m.in. Edward H. Carr (Carr, 1946), Hans Morgenthau (Morgenthau, 2010: 19) i Reinhold Niebuhr (Niebuhr, 1960). Utrzymywali, że w przestrzeni międzynarodowej króluje anarchia i brak zaufania, a możliwość wybuchu wojny jest bardzo prawdopodobna. Realiści krytykowali przy tym międzywojenny liberalizm (zwany też idealizmem) i utyskiwali na optymizm tych, którzy utrzymywali, że stosunki międzynarodowe mogą być bardziej pokojowe dzięki rozwojowi prawa i organizacji międzynarodowych takich jak Liga Narodów. Modyfikację tychże poglądów zaproponował Kenneth Waltz w 1979 r. W jego neorealistycznym ujęciu system międzynarodowy był w dalszym ciagu anarchiczny, ale opierał się na dystrybucji siły/potęgi między państwami (w kierunku równowagi sił) przy odrzuceniu wewnętrznej natury państw (Waltz, 1979).

Zarówno realizm jak i neorealizm czerpały ze wspólnego rdzenia jakim była geopolityka, oparta zwłaszcza na klasycznych pracach Alfreda Mahana (Mahan, 1890) i Halforda Mackindera (Mackinder, 1919), a współcześnie rozwijana w dziełach m.in. Harolda i Margaret Sproutów (Sprout, Sprout, 1971) oraz Ronniego D. Lipschutza (Lipschutz, 1989). Geopolityka odwołuje się do geografii przez podkreślenie przestrzennych wymiarów siły państwa, wskazuje na ciagłą walkę o wpływy i kontrolę nad geograficzną i geopolityczną przestrzenią, którą dla Mackindera był euroazjatycki „heartland" natomiast dla Mahana - przestrzeń morska.

Nietrudno zauważyć, że większość literatury dotyczącej problematyki międzynarodowego wykorzystania energii i bezpieczeństwa energetycznego jest silnie zakorzeniona w podjęciu realistycznym i geopolityce. Zwolennicy takiego podejścia zakładają że:

- dostęp do i kontrola nad surowcami energetycznymi stanowi podstawę siły/potęgi państwa i interesu narodowego;

- surowce energetyczne są coraz rzadsze. Ich zasoby uznaje się w znaczniej mierze niewiadoma; 
- państwa będą w coraz większym stopniu rywalizować o dostęp do tych zasobów i objęcie nad nimi kontroli;

- konflikt i wojna o zasoby energetyczne jest coraz bardziej prawdopodobna, być może nawet nieunikniona.

Na zasadność tych wniosków wskazał m.in. Michael Klare, zauważając szereg tendencji w zakresie dostępu do energii. Podkreślił on: 1) znaczenie ,rynków wschodzących", w post-zimnowojennym świecie, których dążenie do dostępu i kontroli nad surowcami naturalnymi może doprowadzić do zmiany równowagi sił i konfliktu ze starymi mocarstwami, zwłaszcza, USA i UE; 2) wzrost zapotrzebowania na ropę naftową ze strony państw azjatyckich, zwłaszcza Chin; 3) niekorzystne położenie większości złóż surowców energetycznych, w państwach Azji Centralnej i Afryki. Państwa te cechuje słabość struktur administracyjnych, fragmentaryzacja społeczeństw, wzrost ekstremizmu religijnego, często też bezustannie toczone spory graniczne. Posiadanie przez te państwa złóż surowców energetycznych wzmacnia ich pozycję w systemie międzynarodowym, a jednocześnie czyni je niejednokrotnie aktorami ,dysfunkcjonalnymi”, trudnymi do sterowania, rządzonymi autorytarnie i jawnie antyzachodnimi (na co wskazuje związek między bogactwem płynącym z eksploatacji zasobów a odradzaniem się radykalnych ruchów islamskich i zwiększającym się zagrożeniem międzynarodowym terroryzmem) (Klare, 2001; Klare, 2002: 99-104).

Realiści i neorealiści, analizując bezpieczeństwo energetyczne w skali międzynarodowej, skupiają się na podaży energii i szlakach transportowych, którymi jest ona przewożona (większość z nich obejmuje transport morski). Coraz częściej poruszany jest temat „wielkiej gry” w Azji Centralnej, której uczestnikami są Rosja, ChRL i państwa zachodnie. Przedstawiana jest przez neorealistów jako gra o sumie zerowej, której stawką jest dostęp do ogromnych złóż surowców energetycznych (Jafar, 2004; Karasac, 2002). Uwaga też poświęcana jest ekspansji ChRL w Azji Centralnej, Afryce i Ameryce Południowej. Analizuje się dążenie władz chińskich do powiększenia zasobów surowcowych, a także rywalizacji ChRL z sąsiadami regionalnymi - Rosją, Japonią i Indiami. W tym kontekście ciekawy jest przykład ekspansji energetycznej ChRL na „Większy Bliski Wschód” (kraje islamskie Azji Środkowej, Kaukaz, Azja Południowo-Zachodnia, część Półwyspu Bałkańskiego i Afryki Północnej), co zostało przedstawione poniżej, w studium przypadku (I)

\section{Studium przypadku (I) - Chińska strategia energetyczna na „Większym Bliskim Wschodzie”}

W 2002 r. Chiny uznały kwestię energetyki za jeden z priorytetów bezpieczeństwa narodowego. W 2005 roku chińska Rada Państwa pod przewodnictwem premiera Wen Jabao powołała Narodową Grupę Energetyczną składającą się z trzech kontrolowanych przez państwo gigantów energetycznych - China National Petroleum Company, Sinopec, China Offshore Oil Corporation. Kolejnym etapem budowy strategii bezpieczeństwa energetycznego Chin było powołanie w styczniu 2010 r. Narodowej Komisji Energetyki (NEC), w której skład wchodzą przedstawiciele MSZ, Ministerstwa Bezpieczeństwa Narodowego i Sztabu Generalnego Chińskiej Armii Ludowo-Wyzwoleńczej. W pierwszej dekadzie XXI w. Pekin konsekwentnie umacniał swoją pozycję $\mathrm{W}$ dziedzinie energetyki na „Większym Bliskim 
Wschodzie" (kraje islamskie Azja Środkowa, Kaukaz, Azja Południowo- Zachodnia, część Półwyspu Bałkańskiego i Afryki Północnej). Wynikało to z postrzegania przez Chiny bezpieczeństwa energetycznego w kategoriach geopolitycznych i strategicznych, nie zaś czysto ekonomicznych. Strona chińska niechętna była zwłaszcza ropociągowi BTC (Baku-Tblisi-Ceyhan) finansowanemu przez państwa Zachodu i uważnego przez Chińczyków za próbę pozbawienia ich kontroli nad Kaukazem i Azją Środkową. W basenie Morza Kaspijskiego Chiny w największym stopniu inwestują w Kazachstanie, Turkmenistanie, Iranie i Azerbejdżanie W celu zabezpieczenia dostępu do złóż w tym regionie, chiński Narodowy Koncern Paliwowy (National Petroleum Company) w 2009 r. zakończył budowę gazociągu biegnącego przez Azję Środkową, łączącego Turkmenistan z Chinami (zwany Gazociagiem Środkowoazjatyckim, o maksymalnej przepustowości $40 \mathrm{mld} \mathrm{m}^{3}$ gazu rocznie). W lipcu $2009 \mathrm{r}$. zakończono też realizację ropociągu z Kazachstanu do Chin (maksymalna przepustowość $20 \mathrm{mln}$ ton rocznie). W czerwcu 2010 r. prezydent Turkmenistanu Gurbanguly Berdimuhamedow ogłosił rozpoczęcie wartej 2 mld USD inwestycji polegającej na budowie rurociągu łączącego zachodni Turkmenistan z wschodnią częścią Chin. Co do współpracy z Iranem, Pekin zainwestował w irańskie pola naftowe: Północny Azadegan i Południowy Pars. W latach 2005-2010 wartość kontraktów zawartych przez firmy chińskie z irańskim sektorem węglowodorów wyniosła ok. 120 mld USD. W planach są ponadto projekty połączeń gazociaggowych, kolejowych i drogowych między Chinami i Iranem pozwalające na import irańskich zasobów energetycznych drogą lądową z pominięciem szlaków morskich w niestabilnym regionie Zatoki Perskiej. Wszystkie te inicjatywy Pekinu realizowane są w ramach strategii „wychodzenia na zewnątrz". Jest ona próbą uniezależnienia się Chin od transportu morskiego poprzez budowę lądowych rurociągów, gazociągów, linii kolejowych i dróg umożliwiających transport zasobów energetycznych z Bliskiego Wschodu. Polityka ta nazywana jest też „strategią Jedwabnego Szlaku”. Prowadzona jest ona za pomocą Szanghajskiej Organizacji Współpracy'. Realizacja strategii podyktowana jest nie tylko chęcią rozwoju stosunków Chin z państwami Azji Środkowej, Kaukazu i Bliskiego Wschodu, ale także innymi względami strategicznymi. Należy do nich dążenie do kontrolowania przez Pekin głównych szlaków handlowych oraz unikanie konfliktu ze Stanami Zjednoczonymi, których marynarka wojenna patroluje szlaki morskie. W szczególności Chiny obawiają się potencjalnego konfliktu zbrojnego w Cieśninie Tajwańskiej mogącego grozić nałożeniem embarga na dostawy surowców energetycznych. Problem stanowi też napięta sytuacja w Cieśninie Malakka, łączącej Ocean Indyjski z Morzem Południowochińskim, przez którą przewozi się $80 \%$ ropy importowanej do Chin. Szlak ten jest zagrożony atakami piratów oraz potencjalnie przez amerykańską blokadę w razie konfliktu u wybrzeży Tajwanu. W odpowiedzi na te zagrożenia Chiny zwiększają obecność swej marynarki wojennej w Zatoce Adeńskiej

1 Szanghajska Organizacja Współpracy (SCO) powstała w 2001 roku i skupia Rosję, Chiny i państwa środkowoazjatyckie: Kazachstan, Kirgistan, Tadżykistan i Uzbekistan, a także państwa mające status obserwatorów, tj. Iran, Pakistan, Indie, Mongolię. Pekin wykorzystuje SCO w celu przekształcenia części historycznego Jedwabnego Szlaku, przebiegającej przez obszary „Większego Bliskiego Wschodu”, w „trasę energetyczną”. W planach chińskich jest włączenie do SCO Afganistanu i Turkmenistanu, a także zbudowanie w ramach organizacji ropociagu biegnącego z Kazachstanu do Iranu przez Turkmenistan. Pod auspicjami SCO prowadzone są także rozmowy o budowie sieci kolejowej obejmującej Eurazję, łączącej Azję Środkową z Bliskim Wschodem i Europą (tzw. żelazny jedwabny szlak). Służy temu min. podpisanie w 2010 umowy między Chinami i Iranem na budowę linii kolejowej z Teheranu do Khosavi na granicy irackiej, którego część ma prowadzić do Syrii i Libanu, stanowiąc tym samym część Korytarza Bliskowschodniego. Uzasadnieniem tej wartej 2 mld USD inwestycji jest zapewnienie dostępu państwom środkowoazjatyckim do irańskiego portu Chahbahar, natomiast Chinom - lądowego szlaku handlowego umożliwiającego transport towarów do Europy. 
i Azji Południowo-Wschodniej. Pekin stale rozbudowuje marynarkę wojenną, co jest zgodne ze strategią „Nowej Historycznej Misji”, według której Armia Ludowo-Wyzwoleńcza ma odgrywać zasadniczą rolę w obronie narodowych interesów za granicą.

Źródło: G. Xuetang (2006), The Energy Security In Central Kurasia: The Geopolitical Implications to China's Energy Strategy, „China and Eurasia Forum Quarterly”, Vol. 4, No. 4; A. Petersen (2010), Did China Just Win the Caspian Gas War?, „Foreign Policy”, 7.07.2010; S. ZHAO (2008), China's Global Search for Energy Security: Cooperation and Competition in Asian Pacific, „Journal of Contemporary China”, Vol. 55, No. 17; Ch. Lin (2008), Militarisation of China's Energy Security Policy, „Denk Würdigkeiten. Journal der Politisch-Militärischen Gesselschaft”, No. 45; Hu Jintao urges Army to perform ,, Historical Mission”, „Peoples Daily”, 14.03.2005; China, Iran Ink Major Railroad Deal, „Al-Bawaba”, 13.09.2010, http: www.albawaba.com/transport/china-iran-ink-major-railroad-deal.

Stanowisko bliskie realizmowi i myśleniu w kategoriach geopolityki, także w odniesieniu do bezpieczeństwa energetycznego, bywa poddawane krytyce. W szczególności podkreśla się, że realiści przeceniają rolę wojskowego wymiaru potęgi państwa. Co ciekawe, ten argument wysuwają sami neorealiści. Jednym z nich jest Robert Gilpin (Gilpin, 1976, Gilpin, 1987), który zwrócił uwagę na niemilitarne, ekonomiczne czynniki wpływające na siłę państwa w stosunkach międzynarodowych, w tym rosnące znaczenie korporacji transnarodowych. Jeszcze dalej posunęła się Susan Strange zauważając, że rozpatrywanie siły/potęgi państwa w oparciu o czynnik militarny (np. w odniesieniu do bezpieczeństwa energetycznego), ujmowanie relacji między państwami w postaci gry o sumie zerowej i posługiwanie się kategorią konfliktu jest nadmiernym uproszczeniem. W rzeczywistości bowiem o sile państwa, obok czynnika militarnego decydują też jego zdolności produkcyjne (czynnik gospodarczy), kapitał (czynnik finansowy) i wyznawane idee (czynnik ideologiczno-kulturowy) (Strange, Stopford, Heleny, 1991; Strange, 1994). Rozważania na temat roli idei w polityce globalnej rozwija m.in. Joseph Nye jr. Przeciwstawia miękkie (soft) i twarde (hard) aspekty siły/potęgi państwa. Do tych pierwszych zalicza kulturę i ideologię, zwiększające w mało inwazyjny sposób atrakcyjność państwa (Nye, 2004). Należy zauważyć, że współcześnie mamy do czynienia z trzema rywalizującymi ze sobą „,narodowymi konstruktami ideologicznymi", które nieustannie rywalizują ze sobą o palmę pierwszeństwa. Pierwszym z nich jest „konsensus waszyngtoński”, utożsamiany z neoliberalną wizją polityki i gospodarki. Kontrastuje z nim „konsensus pekiński” oparty na kapitalizmie państwowym i limitowaniu swobód obywatelskich. Jako trzeci można uznać „Europejski Model Społeczny” będący ambitną próbą zbudowania pomostu między kapitalizmem, demokracją i ideą państwa dobrobytu.

Drugim z najczęściej wysuwanych argumentów przeciw realizmowi i neorealizmowi jest nadmierne skoncentrowanie się na państwie i międzypaństwowej rywalizacji, przy niedocenianiu roli aktorów transnarodowych (np. wielonarodowych korporacji działających w sektorze wydobywczym) i lokalnych (miejscowe społeczności starające się przejąć kontrolę nad mikroaktywnością wydobywczą w postaci np. objęcia przez górników udziałów w miejscowej kopalni węgla). Na zasadność tej krytyki wskazuje rosnąca waga Szanghajskiej Organizacji Współpracy, będącej instrumentem realizacji polityki Pekinu w regionie Azji Środkowej, a także wzrost znaczenia korporacji takich jak Sinopec - działających w branży paliwowej i zmuszonych do rywalizacji z zachodnimi gigantami w tym sektorze takimi jak: BP, Shell czy Texaco. 
Warto wziąc też pod uwagę argument zaczerpnięty z konstruktywizmu zarzucającego realizmowi nadmierny determinizm tkwiący u jego podstaw. W aspekcie bezpieczeństwa energetycznego konstruktywiści społeczni krytykują aksjomatyczne założenie neorealistów o rzadkości zasobów energetycznych i niechybności konfliktu międzypaństwowego w sytuacji „,szczytowego” (ang. peak oil) zapotrzebowania na ropę $\mathrm{i}$ inne surowce. Neorealistom zarzuca się niedostateczne uwzględnienie w analizach postępu technologicznego, który powala przezwyciężyć problem rzadkości zasobów. Konstruktywiści odsłaniają perspektywę ich zastępowalności. Krytykują także neorealistów za lekceważenie znaczenia rynków międzynarodowych i regionalnych a także instytucji międzynarodowych wpływających na zmniejszanie ryzyka wybuchu, konfliktów. Na różne sposoby wchodzenia w interakcje między państwowymi i niepaństwowymi aktorami stosunków międzynarodowych uwagę zwraca Aleksander Wendt, autor słynnego eseju Anarchy is what states make of it. Wbrew poglądom realistów twierdzi on, że anarchia jest tym co państwa z niej uczynią. Zgodnie z tym poglądem logika anarchii, również w odniesieniu do konfliktu o surowce, może być zastąpiona przez logikę współpracy i współdziałania, na co wskazuje przykład Unii Europejskiej. Pytanie tylko, czy we współczesnym świecie, ogarniętym kryzysem gospodarczym i finansowym państwa, zwłaszcza te największe, najsilniejsze gospodarczo i militarnie, będą chciały postawić na kooperację.

\section{BEZPIECZEŃSTWO ENERGETYCZNE W UJĘCIU (NEO)LIBERALNYM}

Tradycja liberalna w stosunkach międzynarodowych przeciwstawia się realistycznemu pojmowaniu polityki międzynarodowej jako mieszanki realpolitik i geopolityki. U jej źródeł leży odrzucenie rozdziału między politykę krajową i międzynarodową wpływającego na stosowanie odmiennych standardów moralnych, zasad i praktyk postępowania. Liberałowie niechętnie patrzą na stosowanie w domenie międzynarodowej sekretnej dyplomacji, koncentrowanie się na utrzymaniu równowagi sił „za wszelką cenę", ignorowanie, a nawet często okłamywanie opinii publicznej. Na ich argumentację zwracają uwagę coraz częściej sami realiści. Jeden z głównych przedstawicieli tego nurtu - John Mearsheimer - zapytując w jednej ze swoich prac „dlaczego politycy kłamią?" (Mearsheimer, 2012), wbrew potocznemu przeświadczeniu wskazuje, że: „...kłamstwo [...] w polityce międzynarodowej jest akceptowane, ponieważ politycy mają niekiedy ważne strategiczne powody, by okłamywać inne państwa, a nawet swoich obywateli. Mimo to, w relacjach między państwami kłamstwo w istocie nie zdarza się często $[. .$.$] co więcej [\ldots]$ politycy częściej niż inne państwa okłamują swoje społeczeństwa w sprawach polityki zagranicznej. Dotyczy to zwłaszcza krajów demokratycznych prowadzących ambitną politykę zagraniczną i skłonnych przystępować do wojen $\mathrm{z}$ wyboru, a więc w sytuacjach, w których nie występuje wyraźne i bliskie zagrożenie dla ich życiowych interesów możliwe do usunięcia jedynie za pomocą siły" (ibidem: 19-20).

Liberałowie, w odróżnieniu od realistów doceniają znaczenie instytucji międzynarodowych i prawa międzynarodowego. Prawa człowieka, w ujęciu liberalnym, stanowią podstawę indywidualnej autonomii przejawiającej się zarówno w wymiarze 
państwowym, jak i międzynarodowym. Stanowią one podstawę demokratycznego prowadzenia polityki zagranicznej poszczególnych państw. Liberałowie, opierając się na hipotezie „demokratycznego pokoju” wskazują poza tym, że demokracje, w odróżnieniu od reżimów autorytarnych, „nie prowadzą ze sobą wojen” (Russet, 1993). Odrzucając pesymistyczny pogląd realistów o konfliktogennej naturze relacji między podmiotami systemu międzynarodowego podkreślają, że współczesna polityka międzynarodowa staje się coraz bardziej przewidywalna i stabilna dzięki oparciu się na ideach praw człowieka. W wizji liberalnej państwa mają z biegiem czasu ciążyć ku zmianie z autorytaryzmu do demokracji. Powinien temu towarzyszyć wzrost znaczenia regionalnych i globalnych instytucji wspierających współpracę między różnymi aktorami stosunków międzynarodowych (nie tylko państwami) oraz liberalizacja handlu - jako czynniki pozwalające na przezwyciężenie anarchii.

W odniesieniu do międzynarodowych aspektów polityki energetycznej i bezpieczeństwa energetycznego, podejście liberalne skupia się z jednej strony na odsłonieniu „mrocznego wnętrza” sektora energetycznego, z drugiej strony odpowiada na pytanie, co powinno być zrobione, by stworzyć podstawy bardziej otwartego i nastawionego na współpracę systemu porozumień pozwalających uregulować jego funkcjonowanie.

„Mroczne wnętrze" sektora energetycznego jest z perspektywy liberalnej ukazywane jako współwystępowanie licznych, niezgodnych z prawem działań oraz antyliberalnych praktyk wynaturzających politykę, gospodarkę i relacje międzynarodowe. Wśród nich szczególne znaczenie przypisuje się:

- „przekleństwu zasobów” czy też „holenderskiej chorobie” - związkowi między dużą ilością zasobów w danym państwie a słabym poziomem jego rozwoju gospodarczego, wynikającemu z przeznaczenia znakomitej większości środków na wybrany sektor gospodarczy, którego rozrost niejako „pożera” środki wcześniej przeznaczane na inne sektory i przyczynia się do ich kurczenia się

- istnieniu ,państw rentierskich" i konsolidacji neopatrymonialnych reżimów autorytarnych w krajach posiadających bogate złoża surowców, kontestujących idee społeczeństwa obywatelskiego, kładących nacisk na rozwijanie represyjnych funkcji państwa ${ }^{3}$;

2 Zjawisko choroby holenderskiej tłumaczy twierdzenie polskiego ekonomisty Rybczyńskiego. Stwierdził on, że w małym kraju, w warunkach niezmienionych relacji cen na rynku światowym, wzrost zasobów wyłącznie jednego czynnika produkcji, przy niezmienionym poziomie drugiego, prowadzi do wzrostu produkcji dobra zużywającego przede wszystkim czynnik, którego zasoby się powiększają, oraz do zmniejszenia produkcji dobra, w wytwarzaniu którego potrzebny jest przede wszystkim czynnik produkcji, którego zasoby nie ulegają zmianie. Choroba holenderska gospodarki czy inaczej deindustrializacja to zatem regres gospodarczy spowodowany odkryciem i intensywną eksploatacją złóż surowców naturalnych. Pojęcie wprowadził w 1977 r. tygodnik „The Economist”, opisując gospodarcze konsekwencje odkrycia w latach 60. XX w. dużych złóż gazu ziemnego w Holandii. W kraju tym, podobnie jak np. w Wielkiej Brytanii czy Meksyku zaobserwowano, że odkrycie liczących się zasobów surowców (np. gazu ziemnego w Holandii czy ropy naftowej w Meksyku i na Morzu Północnym) spowodowało, że dynamika rozwoju przemysłu w tych krajach zaczęła odstawać od tempa rozwoju górnictwa, co znajdowało także odzwierciedlenie w konkurencyjności ich dóbr na rynku światowym. Por. T. M. Rybczyński (1955), Factor Endowment and Relative Commodity Prices, „Economica”, Vol. 22, No. 84, s. 336-341; A. Budnikowski (2006), Międzynarodowe stosunki gospodarcze, Warszawa, s. 131-132.

3 Publicysta „New York Times” Thomas L. Friedman wskazał na bezpośrednią korelację pomiędzy poziomem cen ropy naftowej a poziomem politycznej wolności, demokratyzacji oraz kierunkiem 
- zjawisku „wojen surowcowych” lub „nowych wojen” - wywoływanych przez agresywne dążenie niektórych państw do pozyskiwania surowców w państwach neopatrymonialnych i podział tych ostatnich między konkurujące ze sobą ośrodki władzy, których priorytetem jest zapewnienie sobie dochodu za wszelką cenę (Kalder, Karl, Said, 2007).

W kontekście analizowania „mrocznego wnętrza” sektora energetycznego zwraca się uwagę na fakt, że państwa uzależnione od dochodów pozyskiwanych z handlu zasobami naturalnymi są często obszarami nadmiernej niestabilności finansowej, zakłóceń w bilansie płatności bieżących oraz ograniczonych możliwości rozwoju gospodarczego. Utrudniany jest on dodatkowo przez nieproporcjonalnie duże oparcie na rencie płynącej z handlu surowcami, co dla miejscowych elit tworzy złudzenie stabilizacji społecznej. Narzędziami służącymi do jej realizacji za są: rozbudowany aparat represji oraz tolerowanie korupcji i całkowitego zakłócenia systemu kontroli i równowagi władz właściwego rozwiniętym demokracjom zachodnim. Problem ten jest charakterystyczny dla państw Zatoki Perskiej, ale także dla innych petrogospodarek. Zdaniem Jewgienija Gontmachera, ekonomisty, byłego wiceministra spraw socjalnych Rosji, od momentu aresztowania i skazania Michaiła Chodorkowskiego oraz likwidacji korporacji Jukos, co nastąpiło w 2003 r., wskazane wyżej problemy silnie ujawniły się w Rosji, której współczesny ustrój określa się mianem „skorumpowanej kleptokracji”. Zdaniem komentatorów rosyjskiej sceny politycznej odpowiedzialny za jego ukształtowanie się jest w znacznej mierze Władimir Putin, który odszedł od ambitnego programu Germana Grefa ${ }^{4}$ przewidującego budowę gospodarki kraju opartej na liberalnych zasadach wolnorynkowych na rzecz budowy kapitalizmu państwowego zniekształcanego stopniowo przez korupcję. Zdaniem Gontmachera „Korupcja zaczęła kwitnąć jeszcze przy B. Jelcynie, kiedy przeprowadzano prywatyzację, pojawili się oligarchowie. Ale to

polityki zagranicznej prowadzonej przez poszczególne kraje. Sformułował on ,,pierwsze prawo petropolityki”, zgodnie z którym im wyższa jest średnia cena ropy naftowej i gazu na rynkach światowych, tym niższe jest przeświadczenie rządów o konieczności przeprowadzenia wewnętrznych reform politycznych i gospodarczych, a ich polityka zagraniczna i bezpieczeństwa jest bardziej konfrontacyjna. Zdaniem T. L. Friedmana prowadzi ona do stanu określanego jako ,petroautorytaryzm”. Przywołana koncepcja pozwala wyjaśnić przede wszystkim politykę zewnętrzną prowadzoną przez państwa uzależnione od produkcji i handlu ropą naftową oraz gazem, takich jak np. Rosja, Iran, Wenezuela, Nigeria, Sudan, dla których charakterystyczny jest niski stopień instytucjonalizacji wewnętrznej i utrzymywanie bardziej lub mniej autorytarnych reżimów. Świat zachodni, w szczególności Stany Zjednoczone Ameryki, uznają ten problem jako negatywny i antydemokratyczny dryf, który powinien być zatrzymany dla dobra bezpieczeństwa światowego. W opinii wyrażanej przez USA i ich sojuszników, opierających swą politykę zagraniczną na neokantowskiej teorii demokratycznego rozwoju, państwa demokratyczne nie prowadzą ze sobą wojen. Zdaniem J. M. Owena, „liberalna ideologia motywuje obywateli przeciwko wojnie z podobnymi sobie demokracjami, a demokratyczne instytucje sprawiają, że ideologia ta ma wpływ na politykę zagraniczną" (por.: T. L. Friedman (2006), The First Law of Petropolitics, „Foreign Policy”; Vol. 154, No. 3; M. W. Doyle (1983), Kant, Liberal Legacies, and Foreign Affairs, „Philosophy and Public Affairs”, Vol. 12, No. 3; M. W. Doyle (1983), Kant, Liberal Legacies, and Foreign Affairs, Part 2, „Philosophy and Public Affairs”, Vol. 12, No. 4; J. M. Owen (1994), How Liberalism Produces Democratic Peace, „International Security”, Vol. 19, No. 2; M. Rewizorski (2011), Petropolityka i bezpieczeństwo energetyczne we wspótczesnym świecie, „Przegląd Strategiczny”, nr 2, s. 312).

4 German Gref był ministrem rozwoju gospodarczego Federacji Rosyjskiej. 
W. Putin doprowadził ten proces do końca. W rezultacie całe [...] państwo zostało absolutnie sprywatyzowane i pracuje tylko w interesie określonej wąskiej grupy. Nad tym czuwają instytucje państwowe, takie jak sądy, milicja, służby specjalne, podporządkowane władzy media. Korupcja stała się jedynym działającym mechanizmem regulującym życie społeczeństwa. Już nawet nie możemy mówić, że mamy w Rosji kapitalizm państwowy, bo w rzeczywistości nie mamy państwa z działającymi i służącymi społeczeństwu instytucjami (Radziwinowicz, 2011). W opinii J. Gontmachera Rosja już w obecnej mierze płaci wysoki rachunek za zaniechanie demokratycznych reform, a pokrywają go wpływy za handlu ropą naftową i gazem ziemnym, które nie są jednak inwestowane w najbardziej potrzebną infrastrukturę pozwalającą Rosji na wstąpienie na ścieżkę dynamicznego rozwoju. W interesującej i pozostawiającej wiele miejsca do polemiki wypowiedzi J. Gontmacher zauważa: „Kraj zatrzymał się w rozwoju i beznadziejnie traci dystans do świata. I to w latach, kiedy mieliśmy niezwykle sprzyjająca koniunkturę. Paradoksalnie ta koniunktura, przede wszystkim wysokie ceny paliw, nam zaszkodziła. Gdyby ropa i gaz były tańsze, trzeba by było coś wymyślać, rozwijać, reformować, inaczej układać relacje z Zachodem. A kiedy petrodolary płynęły do nas rzeką, można było nic nie zmieniać i spokojnie kraść. Nie staliśmy się pełnoprawnym członkiem G8, grupy państw mających największe znaczenie na świecie. Teraz członkowie tego klubu naradzają się, jak sobie poradzić z kryzysem, ale robią to bez nas, bo nasz głos nie ma znaczenia ${ }^{5}$. Nie podnieśliśmy poziomu życia zdecydowanej większości społeczeństwa. Rosjanie pozbawieni prawa uczestniczenia w życiu publicznym stali się bierni, apatyczni” (ibidem).

$\mathrm{Na}$ znacznie większą skalę $\mathrm{z}$ handlu energią korzystają autokraci lub dyktatorzy rządzący państwami arabskimi, którzy często dla zachodnich koncernów energetycznych są gwarantami wysokich zysków, a dla państw Zachodu - politycznymi sprzymierzeńcami w regionie. Przestają nimi być jedynie w przypadku zajścia zdarzeń trudnych do przewidzenia, gwałtownych, o dużej wymowie aksjologicznej, jednoczących wcześniej podzielone i apatyczne społeczności wokół silnie wyodrębnionych celów politycznych i ekonomicznych. Do takich wydarzeń można zaliczyć Arabska wiosnę, której iskrę stanowiło samospalenie 18 grudnia 2010 r. Tunezyjczyka Mohammada Buzaziego. Wkrótce po tym zdarzeniu transparenty niesione przez tysiące demonstrantów w Tunisie, Bagdadzie, Kairze, Rabacie czy Algierze zaczęły domagać się swobody politycznej, zmiany władzy, rozprawienia się z korupcja, zlikwidowania opresyjnych aparatów bezpieczeństwa, a także zapewnienia godziwych wynagrodzeń (Korm, 2011: 16). Na pierwszy plan wysunęły się wcześniej tłumione kwestie gospodarcze i społecz-

5 Według stanu na wrzesień 2014 r. członkostwo Rosji w G8 jest zawieszone ze względu na naruszenie suwerenności i integralności terytorialnej Ukrainy, co stoi w sprzeczności z rosyjskimi zobowiązaniami wynikającymi z Karty Narodów Zjednoczonych, a także z umowy dwustronnej, która związała Rosję i Ukrainę w 1997 r. Decyzja o zawieszeniu Rosji w G8 została podjęta oraz opublikowana przez przywódców Kanady, Niemiec, Włoch, Japonii, Wielkiej Brytanii, Stanów Zjednoczonych, a także UE, reprezentowanej przez przewodniczących Rady Europejskiej oraz Komisji dnia 2 marca 2014 r. Przywódcy grupy zawiesili także swój udział w przygotowaniach do jej szczytu zaplanowanego w lipcu 2014 w miejscowości Sochi. Szczyt G8 został przeniesiony do Brukseli. Rosja nie wzięła w nim udziału. Patrz: http://www.whitehouse.gov/the-press-office/2014/03/02/g-7-leaders-statement (5.07.2014). 
ne, stosunkowo rzadko zauważane przez obserwatorów wydarzeń z Europy i Stanów Zjednoczonych. Ich znaczenia nie były w stanie zanegować ani walczące o utrzymanie się reżimy, ani też popierający je autokraci i dyktatorzy na czele z Hugo Chavezem, Danielem Ortegą i Fidelem Castro ${ }^{6}$. Przykładem może być Libia, która do czasu wybuchu rewolucji w Afryce Północnej była zarządzana twardą ręką przez Muammara Kaddafiego. Zarówno dla MFW, chwalącego Libię za bardzo dobre wyniki makroekonomiczne i postępy w umacnianiu sektora prywatnego, jak i państw zachodnich kwestia dramatycznych warunków życia miejscowej społeczności stanowiła sprawę drugorzędną, podporządkowaną prymatowi ekonomii i geopolityki. W dłuższej perspektywie nie przeszkadzało im umieszczenie Libii w grudniu 1979 roku przez amerykański Departament Stanu na liście państw wspierających terroryzm, zamknięcie ambasady amerykańskiej w Trypolisie, a także zamachy na samoloty - pasażerski Boeing 747 linii Pan Am nad Lockerbie 21 grudnia 1988 r. oraz DC-10 francuskiej kompanii UTA w listopadzie 1989 r., które zakończyły się międzynarodowymi sankcjami, zniesionymi w listopadzie 2003 roku. Uwagę wzbudziły dopiero protesty zmęczonego korupcją i brakiem wolności społeczeństwa libijskiego, które w połowie 2010 r. coraz dobitniej wyrażało swoje niezadowolenie. Arabska wiosna i wojna domowa w Libii uświadomiły też państwom Zatoki Perskiej, że aby utrzymać dotychczasowe reżimy konieczne jest kupienie pokoju społecznego. Podstawowy problem stanowi tutaj eksplozja demograficzna. Dwie trzecie ludności na Bliskim Wschodzie ma mniej niż trzydzieści lat, co stanowi wielki kapitał, który odpowiednio spożytkowany może być czynnikiem wzrostu gospodarczego i stabilizacji. Jednakże przedłużający się brak perspektyw dla młodych ludzi wynikający z nieprzeprowadzenia koniecznych reform gospodarczych może prowadzić do ich wykluczenia społecznego, a w efekcie również do pojawienia się napięć w każdej chwili grożących wybuchem niezadowolenia na wielką skalę (Dhillon, 2008). Aby należycie skorzystać z zasobów ludzkich państwa Zatoki Perskiej będą musiały przyjać, najpóźniej do 2020 roku, programy umożliwiające stworzenie około $80 \mathrm{mln}$ nowych miejsc pracy w sektorze prywatnym oraz dokonać inwestycji w sektorze edukacyjnym.

Podejście liberalne odsłania nie tylko „mroczne wnętrze” tj. antyliberalne praktyki i zasady postępowania w sektorze energetycznym, ale odpowiada też na pytanie, co powinno być zrobione, aby powyższe praktyki i zasady ,ucywilizować”. Propozycje $\mathrm{w}$ tym zakresie są zgłaszane $\mathrm{z}$ różnych źródeł. Obok neoklasycznych ekonomistów i zaangażowanych społecznie naukowców, propozycje zmian przedstawiają międzynaro-

${ }^{6}$ W odniesieniu do Libii liczne lewicowe rządy latynoamerykańskie (Wenezuela, Kuba, Nikaragua, Boliwia) przez długi czas milczały na temat represji zarządzonych przez Kaddafiego, a państwa zachodnie wyrażały jedynie fasadowy sprzeciw wobec prowadzonej przez niego polityki. Z kolei Kaddafi przez wiele lat przekonywał o „spisku kolonialnym”, którego padł ofiarą, jednocześnie zapewniając mocarstwa kolonialne: ,toczymy tę samą walkę z terroryzmem. Nasze wywiady współpracują ze sobą. W ostatnich latach bardzo wam pomogliśmy”. Libijskiemu dyktatorowi twierdzącemu, że atak, którego padł ofiara, jest spowodowany pragnieniem pozyskania kontroli nad libijską ropą naftową nie przeszkadzał fakt, że w momencie rozpoczęcia Arabskiej wiosny ropę tę eksploatowała kompania amerykańska Occidental, brytyjska BP i włoska ENI. Por. S. Halami (2011), Sidła wojny, „Le Monde Diplomatique”, nr 4 (62), s. 14. 
dowe instytucje finansowe, a także NGO, takie jak Global Witness czy Revenue Watch. Dotyczą one zazwyczaj:

- propagowania przejrzystości i otwartości w dostępie do informacji dotyczących polityki energetycznej;

- ustanowienia międzynarodowych regulacji mających na celu ograniczyć nielegalny handel surowcami. Przykładem jest tzw. Kimberley Process, uzgodnienie mające na celu rozwiązać problem handlu diamentami i związanych z tym konfliktów w wielu częściach Afryki;

- promowania idei społecznej odpowiedzialności przedsiębiorstw, którą definiuje się najczęściej w trzech wymiarach: a) odpowiedzialności korporacji za wpływ ich działań na miejscową społeczność i środowisko naturalne; b) odpowiedzialność korporacji za zachowanie innych podmiotów, z którymi prowadzą interesy (np. w ramach tzw. łańcucha podażowego); c) odpowiedzialności korporacji za wytwarzanie wartości dodanej wykraczającej poza względy czysto pragmatyczne (maksymalizacja zysku) i przez to wkład w budowanie społeczności lokalnych (Frynas, 2009: 6). Warto w tym miejscu dodać, że w szczególności międzynarodowe firmy zajmujące się pozyskiwaniem ropy naftowej, gazu i węgla są pod silną presją ze strony organizacji obywatelskich wskazujących na szkody środowiskowe wywoływane przez działalność korporacji, a także utrwalanie niestabilności w regionach, gdzie istnieje wiele ośrodków władzy, często nieuznających władz centralnych. Presja wywierana na firmy takie jak: Petrobras, India Oil czy Kuwait Petroleum coraz częściej skutkuje wypracowaniem przez nie kodeksów dobrych praktyk, a także podejmowaniem współpracy z ONZ w ramach tzw. UN Global Compact - programu określanego przez 10 zasad odnoszących się do przestrzegania praw człowieka, ochrony środowiska i działań antykorupcyjnych;

- praktyk dobrego zarządzania (ang. good governance), które można w ogólności określać jako „prawdziwą polityczną równość... demokratyczną kulturę relacji społecznych, opartą na uczciwych, przejrzystych i wiarygodnych procedurach" (Kalder, Karl, Said, 2007: 279), a w węższym aspekcie bezpieczeństwa energetycznego - jako akceptowane sposoby zarządzania obrotem surowcami energetycznymi w celu zapobiegania nadmiernym fluktuacjom ich cen na rynkach międzynarodowych (Fasano, 2000);

- promocji regionalnych i międzynarodowych reżimów i instytucji energetycznych. Wśród nich szczególne miejsce zajmują liberalne międzynarodowe reżimy takie jak IEA czy Energy Charter Treaty, które mają za zadanie ułatwianie współpracy międzynarodowej w dziedzinie energii. Wskazuje się też na projekty tworzenia regionalnych instytucji energetycznych w Południowej i Północno-Wschodniej Azji mające ułatwiać współpracę w sektorze energetycznym między Chinami, Rosją i Japonią. Wiele do życzenia pozostawia polityka energetyczna prowadzona przez UE. Zarzuca jej się niedostateczny stopień liberalizacji i instytucjonalizacji (studium przypadku II). W szczególności perspektywę instytucjonalizacji sektora energetycznego rozwijają Andreas Goldthau i Jan Martin Witte w artykule opublikowanym w 2009 r. na łamach pisma „International Affairs” (Goldthau, Witte, 2009), a także w wydanej w 2010 r. książce, stanowiącej jego rozwinięcie (Goldthau, Witte, 2010). Ich zdaniem kluczowe dla zrozumienia sposobu funkcjonowania sektora energetycznego 
w wymiarze międzynarodowym jest dostrzeżenie roli i dynamiki rynków, a to wymaga opisania i zdefiniowania zasad, według których one działają. Zasady te określa się mianem instytucji (Szlagowski, 2013: 286). Wskazuje na to m.in. Douglas North stwierdzając, że ,instytucje są stworzonymi przez człowieka ograniczeniami, które tworzą strukturę interakcji politycznych, ekonomicznych i społecznych. Składają się zarówno z nieformalnych ograniczeń (sankcje, tabu zwyczaje, tradycje), jak i formalnych reguł (takich jak: konstytucje, ustawy, prawa własności)". Instytucje te, wraz ze standardowymi ograniczeniami gospodarczymi, określają zakres wyboru wpływając na koszty transakcyjne, rentowność i wykonalność przedsięwzięć gospodarczych (North, 1991: 95). Mają one służyć korygowaniu niedoskonałości rynków, obniżaniu kosztów transakcyjnych i tworzeniu reguł obrotu rynkowego (Szlagowski, 2013: 287);

- liberalizacji gospodarczej - zgodne z którą jeżeli obrót energią zostałby ułatwiony, a handel surowcami energetycznymi byłby prowadzony zgodnie z ricardiańską zasadą korzyści komparatywnych, zasoby byłby dostarczane w najbardziej efektywny sposób bez ryzyka wstrząsów wywoływanych przez „geopolityczną rywalizację”, konflikt, a nawet wojnę o dostęp do rzadkich surowców.

\section{Studium Przypadku (II) \\ - Problem instytucjonalizacji polityki energetycznej Unii Europejskiej}

Unia Europejska (wcześniej Wspólnota Europejska) stara się budować politykę energetycznąjuż od lat 70. ubiegłego wieku. Wpływ na to miał kryzys naftowy, który szczególnie dotkliwie dotknął świat Zachodu w latach 1971-1984. Wychodząc naprzeciw zarzutom o niedostatecznym poziomie instytucjonalizacji polityki energetycznej, państwa członkowskie UE w Traktacie o funkcjonowaniu Unii Europejskiej (TFUE), obowiązującym od grudnia 2009 roku, zdecydowały się utworzyć tytuł XXI poświęcony energetyce. Zgodnie z art. 194 ust. 1 TFUE do celów polityki energetycznej UE zalicza się: 1) zapewnienie funkcjonowania rynku energii; 2) zapewnienie bezpieczeństwa dostaw energii w Unii; 3) wspieranie efektywności energetycznej i oszczędność energii; 4) wspieranie wzajemnych połączeń między sieciami energii. Cele te mają być realizowane w duchu solidarności, co wskazano w art. 122 TFUE. Zgodnie z jego treścią „...Rada, na wniosek Komisji, może postanowić, w duchu solidarności między Państwami Członkowskimi, o środkach stosownych do sytuacji gospodarczej, w szczególności w przypadku wystąpienia poważnych trudności w zaopatrzeniu w niektóre produkty, zwłaszcza w obszarze energii”. Zapis ten ma przyczyniać się do zwiększenia bezpieczeństwa energetycznego UE. Nie stanowi on jednak „twardego" zobowiązania do wzajemnej solidarności między państwami UE w przypadku kryzysu zaopatrzenia. Podobnie jak rozporządzenie PE i Rady (UE) nr 994/2010 w sprawie środków zapewniajacych bezpieczeństwo dostaw gazu ziemnego, jest raczej reakcją na konsekwencje sporu między Ukrainą a Rosją, niż zdecydowanym działaniem prowadzącym do wzmocnienia unijnej polityki energetycznej. Pomimo, że „energetyka” po traktacie z Lizbony jest wypadkową decyzji instytucji unijnych i państw w ramach kompetencji dzielonych, w wielu kwestiach trudno będzie o uzyskanie kompromisu. Państwa, kierując się żywotnym interesem będą dążyły do zachowania kontroli nad krajowymi zasobami surowców energetycznych oraz autonomii w kwestiach opodatkowania energii, niechętnie przy tym patrząc na rozbudowywanie kompetencji instytucji unijnych. Do tego rozdźwięku prowadzą same postanowienia TFUE. W art. 194 ust. 2 i 3 przewidziano, że decyzje dotyczące opodatkowania energetyki i praw państw członkowskich do 
określania warunków wykorzystania swoich zasobów energetycznych, wyboru między źródłami energii i ogólnej struktury zaopatrzenia w energię wymagają jednomyślności. Ten zapis może w przyszłości zniweczyć wspomniany art. 194 ust. 1, poświęcony zapewnieniu solidarności energetycznej i stanowi odwrót metody wspólnotowej, której podstawę stanowi podejmowanie decyzji za pomocą większości kwalifikowanej. Co więcej, państwom członkowskim po traktacie z Lizbony w dziedzinie energetyki pozostawiono prawo do utrzymywania i kształtowania dwustronnych relacji z krajami niebędącymi członkami Unii Europejskiej, z tym wszakże zastrzeżeniem, że państwa UE powinny respektować w działaniu zasadę solidarności, przestrzegać europejskiego prawa konkurencji, zwłaszcza w zakresie importu i tranzytu surowców energetycznych. Teoretycznie zatem wyklucza to osobne, ,separatystyczne”, bo wykraczające poza ramy unijnej polityki zagranicznej, bliskie relacje energetyczne między poszczególnymi państwami UE a państwami rządzonymi autorytarnie, takimi jak Rosja czy Iran. Należy jednak pamiętać, że duch wspólnotowy jest po traktacie z Lizbony osłabiony przez niejednoznaczne określenie tego kto rządzi Unią, jak też kto reprezentuje ją na zewnątrz. Trójpodział władzy między trio prezydencjalne, Wysokiego Przedstawiciela ds. Zagranicznych i Polityki Bezpieczeństwa oraz Przewodniczącego Rady Europejskiej nie służy prowadzeniu polityki energetycznej, będącej już obecnie strategiczną, żywotną sferą aktywności nie tylko samych państw członkowskich, ale też samej UE. Na tym tle zauważalny jest nabrzmiały konflikt polityczny między Komisją a Radą o to kto ma reprezentować Unię na zewnątrz i prezentować jej stanowisko w przedmiocie polityki energetycznej. Rozwiązanie tego problemu utrudnia fakt, że sama polityka energetyczna po traktacie z Lizbony jest regulowana zarówno w osobnym tytule XXI, a jednocześnie stanowi część polityki zagranicznej (poprzez związek energetyki z innowacjami technologicznymi i rozwijaniem relacji z państwami producenckimi i tranzytowymi), polityki ochrony środowiska (redukcja emisji $\mathrm{CO}_{2} \mathrm{i}$ inwestycje w odnawialne źródła energii), polityki konkurencyjności (zapewnienie przemysłowi europejskiemu dostępu do źródeł energii po przystępnych cenach). Polityka energetyczna w UE ma zatem charakter międzysektorowy. Staje się ona terenem rywalizacji Komisji i Rady. Zdaniem m.in. Macieja Kaczyńskiego, Marka Rewizorskiego i Beaty Przybylskiej-Maszner instytucje te po traktacie $\mathrm{z}$ Lizbony zostały zmarginalizowane kosztem Parlamentu Europejskiego i Rady Europejskiej, które stały się „super-centrami” władzy w UE. Co więcej, polityka energetyczna jest obszarem szczególnie „wrażliwym” i niechętnie poddawanym pod negocjacje przez państwa członkowskie. Powyższe rozważania prowadzą do wniosku, iż unijna polityka energetyczna jest wciąż w bardzo wczesnej, wręcz ,embrionalnej” fazie rozwoju, czemu nie pomagają niejednoznaczne, a miejscami wręcz nieprzemyślane i krzyżujące się, postanowienia TFUE. W tym kontekście wydaje się, że trudno będzie realizować Europejską Energetyczną Mapę Drogową 2050, a także skutecznie przeciwstawiać się rosyjskiej ekspansji w zakresie energetyki.

Źródlo: J. F. Braun (2011), EU Energy Policy Under the Treaty of Lisbon Rules. Between a New Policy and Business as Usual, EPIN Working Paper No. 31; Traktat z Lizbony zmieniajacy Traktat o Unii Europejskiej i Traktat ustanawiajacy Wspólnotę Europejska, Dz. U. C 306 z 17 grudnia 2007 r.; Rozporządzenie Parlamentu Europejskiego i Rady (UE) nr 994/2010 z dnia 20 października 2010 roku w sprawie środków zapewniajacych bezpieczeństwo dostaw gazu ziemnego $i$ uchylenia dyrektywy Rady 2004/67/WE, Dz. Urz. UE L 295/1, 12.02.2010; P. M. Kaczyński, P. Ó Broin, F. Dehousse, P. de Schouthette, T. Heremans, J. Keller, G. Milton, N. Witney, J. Emmanouilidis, A. Missiroli, C. Stratulat (2010), The Treaty of Lisbon: A Second Look at the Institutional Innovations, Centrum Polityki Europejskiej Egmont/Centrum Studiów nad Polityką Europejską, Bruksela; D. Dinan (2010), Institutions and Governance: A New Treaty, a Newly Elected Parliament and a New Commission, „Journal of Common Market Studies Annual Review", Vol. 48, suplement; M. Rewizorski, B. Przybylska-Maszner (2012), System instytucjonalny Unii Europejskiej po traktacie z Lizbony. Aspekty polityczne i prawne, Difin, Warszawa, s. $48-50$. 
W dużym uproszczeniu bezpieczeństwo energetyczne można utożsamiać z bezpieczeństwem dostaw, czyli zabezpieczeniem fizycznych i nieprzerwanych dostaw „,energii” dla społeczeństwa i gospodarki, przy założeniu, że ceny jej będą dostępne dla wszystkich konsumentów. O rynku energii decydują państwa, choć trzeba przyznać, że w coraz większej mierze ograniczają je korporacje transnarodowe, organizacje między- i pozarządowe, i inne, nieterytorialne podmioty stosunków międzynarodowych. Przy rozpatrywaniu problematyki bezpieczeństwa energetycznego, naturalne jest przyjęcie optyki neorealistycznej, pozwalającej na ukazanie szeregu zagrożeń wynikających z tego, że: 1) dostęp do i kontrola nad surowcami energetycznymi stanowi podstawę siły/potęgi państwa i interesu narodowego; 2) surowce energetyczne są coraz rzadsze; 3) ich zasoby uznaje się w znaczniej mierze niewiadomą; 4) państwa będą w coraz większym stopniu rywalizować o dostęp do tych zasobów i objęcie nad nimi kontroli; 5) konflikt i wojna o zasoby energetyczne są coraz bardziej prawdopodobne.

Neorealiści nie bez racji wskazuja, na szereg tendencji w zakresie dostępu do energii. Podkreślają oni: 1) znaczenie „rynków wschodzących”, w post-zimnowojennym świecie, których dążenie do dostępu i kontroli nad surowcami naturalnymi może doprowadzić do zmiany równowagi siły i konfliktu ze starymi mocarstwami, zwłaszcza, USA i UE; 2) wzrost zapotrzebowania na ropę naftową ze strony państw azjatyckich, zwłaszcza Chin; 3) niekorzystne położenie większości złóż surowców energetycznych, w państwach Azji Centralnej i Afryki, które cechuje słabość struktur administracyjnych, fragmentaryzacja społeczeństw, wzrost ekstremizmu religijnego, często też bezustannie toczone spory graniczne.

$\mathrm{Z}$ drugiej strony, niejako dla zbilansowania nadmiernie „militarystycznego" ujęcia neorealistycznego, warto też wskazać na neoliberalną interpretację bezpieczeństwa energetycznego. W odniesieniu do międzynarodowych aspektów polityki energetycznej i bezpieczeństwa energetycznego, podejście liberalne skupia się z jednej strony na odsłonieniu „mrocznego wnętrza” sektora energetycznego, z drugiej strony odpowiada na pytanie, co powinno być zrobione, by stworzyć podstawy bardziej otwartego i nastawionego na współpracę systemu porozumień pozwalających uregulować jego funkcjonowanie. Wśród propozycji znajdziemy tu m.in.: 1) działania nakierowane na propagowanie przejrzystości i otwartości w dostępie do informacji dotyczących polityki energetycznej; 2) postulaty ustanowienia międzynarodowych regulacji mających na celu ograniczyć nielegalny handel surowcami; 3) promowanie idei społecznej odpowiedzialności przedsiębiorstw; 4) dbałość o zapewnienie praktyk dobrego zarządzania, które w aspekcie bezpieczeństwa energetycznego - jako akceptowane sposoby zarządzania obrotem surowcami energetycznymi w celu zapobiegania nadmiernym fluktuacjom ich cen na rynkach międzynarodowych; 5) promocję regionalnych i międzynarodowych reżimów i instytucji energetycznych; 6) liberalizację gospodarczą - zgodnie z którą jeżeli obrót energią zostałby ułatwiony, a handel surowcami energetycznymi byłby prowadzony zgodnie z ricardiańską zasadą korzyści komparatywnych, zasoby byłby dostarczane w najbardziej efektywny sposób bez ryzyka wstrząsów wywoływanych przez „geopolityczną rywalizację", konflikt, a nawet wojnę o dostęp do rzadkich surowców. 
Ogólnie rzecz ujmując, te dwa podejścia teoretyczne są ,kompatybilne” $\mathrm{z}$ tradycyjnymi ujęciami bezpieczeństwa - ,negatywnym” (właściwym neorealizmowi) i pozytywnym (właściwym neoliberalizmowi). Oczywiście obok nich występuje szereg innych nurtów myślenia o bezpieczeństwie - inspirowanych głównie przez konstruktywizm społeczny, szkołę angielską i strukturalizm. Jednakże gros rozważań na temat bezpieczeństwa energetycznego odbywa się w obrębie „debaty neo-neo”. Dotyczy to także Unii Europejskiej. Świadczą o tym niekończące się dyskusje na temat kształtu unijnej polityki energetycznej. Poglądy zbliżone do neoliberalizmu przyjmują w niej ponadnarodowe instytucje, takie jak Komisja starająca się bronić stanowiska UE względem rosyjskiego potentata naftowego Gazprom. Z kolei państwa UE traktują sprawy energetyczne jako ,żywotne interesy” i z dużą niechęcią spoglądają na zakusy instytucji UE, dążących do pozyskiwania w tym zakresie coraz to nowych uprawnień. Współcześnie, w obliczu kryzysu gospodarczego i finansowego w Europie, wydaje się, że na znaczeniu zyskują poglądy zwolenników neorealistycznego podejścia do bezpieczeństwa energetycznego. Trudno się temu dziwić. W okresach braku prosperity jednostki, grupy społeczne, liderzy opinii odwołują się do państw i kategorii interesu narodowego głośno skandując state is back. Biorąc ponadto pod uwagę problem wyczerpywania się surowców energetycznych i wysokie koszty nowych technologii pozyskiwania energii można się spodziewać, że to właśnie państwa w najbliższych latach będą ,rozdawać karty” na rynkach energetycznych.

\section{Bibliografia}

Braun J. F. (2011), EU Energy Policy Under the Treaty of Lisbon Rules. Between a New Policy and Business as Usual, EPIN Working Paper, No. 31.

Budnikowski A. (2006), Międzynarodowe stosunki gospodarcze, Warszawa.

Carr E. H. (1946), The Twenty Years Crisis: an Introduction to the Study of International Relations, London.

China, Iran Ink Major Railroad Deal, „Al-Bawaba”, 13.09.2010, http://www.albawaba.com/transport/china-iran-ink-major-railroad-deal (10.12.2013).

Dhillon N., Middle East Youth Bulge: Challenge or Opportunity?, http://www.brookings.edu/speeches/2008/0522_middle_east_youth_dhillon.aspx (22.05.2008).

Dinan D. (2010), Institutions and Governance: A New Treaty, a Newly Elected Parliament and a New Commission, „Journal of Common Market Studies Annual Review”, Vol. 48, Supplement, DOI: $10.1111 / \mathrm{j} .1468-5965.2010 .02096 . x$.

Doyle M. W. (1983), Kant, Liberal Legacies, and Foreign Affairs, „Philosophy and Public Affairs”, Vol. 12, No. 3.

Doyle M. W. (1983), Kant, Liberal Legacies, and Foreign Affairs, Part 2, „Philosophy and Public Affairs", Vol. 12, No. 4.

Fasano U (2000), Review of the Experience with Oil Stabilization and Savings Funds in Selected Countries, „IMF Working Paper” 2000, WP/oo/112.

Friedman T. L. (2006), The First Law of Petropolitics, „Foreign Policy”, Vol. 154, No. 3.

Frynas J. G. (2009), Beyond Corporate Social Responsibility. Oil Multinationals and Social Challenges, Cambridge. 
Gilpin R. (1097), The Political Economy of International Relations, Princeton.

Gilpin R. (1976), US Power and the Multinational Company: The Political Economy of Foreign Direct Investment, London.

Goldthau A., Witte J. M. (2009), Back to the future or forward to the past? Strenghtening markets and rules for effective global energy governance, „International Affairs”, Vol. 85, No. 2, DOI: 10.1111/j.1468-2346.2009.00798.x.

Goldthau A., Witte J. M. (eds.) (2010), Global Energy Governance: The New Rules of the Game, Berlin-Washington D.C.

Halami S. (2011), Sidła wojny, „Le Monde Diplomatique”, nr 4 (62).

Hu Jintao urges Army to perform „Historical Mission”, „Peoples Daily”, 14.03.2005.

Jafar M. (2004), Kazachstan: Oil. Politics and the New „Great Game”, w: The Caspian: Politics, Energy and Security, (ed.) S. Akiner, London 2004.

Kaczyński P. M., Broin P. Ó, Dehousse F., de Schouthette P., Heremans T., Keller J., Milton G., Witney N., Emmanouilidis J., Missiroli A., Stratulat C. (2010), The Treaty of Lisbon: A Second Look at the Institutional Innovations, Centrum Polityki Europejskiej Egmont/Centrum Studiów nad Polityką Europejską, Bruksela.

Kalder M., Karl T. L., Said Y. (2007), Oil Wars, London.

Karasac H. (2002), Actors of the New , Great Game”, „Caspian Oil Politics, Journal of Southern Europe and Balkans", Vol. 4, No. 1, DOI:10.1080/14613190220130269.

Klare M. (2002), Global Petropolitics: The Foreign Policy Implications of the Bush Administration's Energy Plan, „Current History”, Vol. 101, No. 653.

Klare M. (2001), Resource Wars, New York.

Korm G. (2011), Odnaleziona arabska jedność, „Le Monde Diplomatique”, nr 4 (62).

Lin Ch. (2008), Militarisation of China's Energy Security Policy, „Denk Würdigkeiten. Journal der Politisch-Militärischen Gesselschaft", No. 45.

Lipschutz R. D. (1989), When Nations Cash: Raw Material, Ideology and Foreign Policy, London.

Mackinder H. (1919), Democratic Ideas and Realism: A Study of Politics of Reconstruction, London.

Mahan A. T. (1890), The Influence of Sea Power upon History, Hill and Wang, New York.

Mearsheimer J. J. (2012), Dlaczego politycy kłamia, thum. G. Łuczkiewicz, Warszawa.

Morgenthau H. J. (2010), Polityka między narodami. Walka o potęge i pokój, Warszawa.

Niebuhr R. (1960), Moral Man and Immoral Society: A Study in Ethics and Politics, New York.

North D. D. (1991), Institutions, „Journal of Economic Perspectives”, Vol. 5, No. 1, DOI: $10.1257 /$ jep.5.1.97.

Nye J. S. (2004), Soft Power: the means to success in world politics, New York.

Owen J. M. (1994), How Liberalism Produces Democratic Peace, „International Security”, Vol. 19, No. 2.

Paarlberg R. (1978), Food, Oil, and Coercive Resource Power, „International Security”, Vol. 3, No. 2 (Autumn).

Petersen P. (2010), Did China Just Win the Caspian Gas War?, „Foreign Policy”.

Radziwinowicz J. (2011), Rosja Putina stuży ,, skorumpowanej kleptokracji”, rozmowa W. Radziwinowicza z J. Gontmacherem, „Gazeta Wyborcza”, 9.08.2011.

Rewizorski M. (2011), Petropolityka i bezpieczeństwo energetyczne we współczesnym świecie, „Przegląd Strategiczny”, nr 2.

Rewizorski M., Przybylska-Maszner B. (2012), System instytucjonalny Unii Europejskiej po traktacie z Lizbony. Aspekty polityczne i prawne, Warszawa. 
Rozporządzenie Parlamentu Europejskiego i Rady (UE) nr 994/2010 z 20 października 2010 roku w sprawie środków zapewniajacych bezpieczeństwo dostaw gazu ziemnego i uchylenia dyrektywy Rady 2004/67/WE, Dz. Urz. UE L 295/1, 12.02.2010.

Russet B. M. (1993), Grasping the Democratic Peace: Principles for a post-cold War World, Princeton.

Rybczyński T. M. (1955), Factor Endowment and Relative Commodity Prices, „Economica”, Vol. 22 , No. 84.

Sprout H., Sprout M. (1971), Towards a Politics of Planet Earth, New York.

Strange S. (1994), States and Markets, London.

Strange S., Stopford J., Heleny J. S. (1991), Real States, Real Firms: Competition for World Markets.

Szlagowski P. (2013), Niedoceniana struktura instytucjonalna sektora energetycznego, „Nowa Europa" I (14).

Traktat z Lizbony zmieniajacy Traktat o Unii Europejskiej i Traktat ustanawiajacy Wspólnotę Europejska (2007), Dz. U. C 306, 17.12.2007.

Waltz K. N. (1979), Theory of International Politics, New York.

Xuetang G. (2006), The Energy Security In Central Kurasia: The Geopolitical Implications to China's Energy Strategy, „China and Eurasia Forum Quarterly”, Vol. 4, No. 4.

Zhao S. (2008), China's Global Search for Energy Security: Cooperation and Competition in Asian Pacific, „Journal of Contemporary China”, Vol. 55, No. 17,

DOI:10.1080/10670560701809460.

\title{
STRESZCZENIE
}

Celem niniejszego artykułu jest ukazanie rozbieżności między ujęciem neorealistycznym a neoliberalnym w odniesieniu do problematyki bezpieczeństwa energetycznego, ale także zanalizowanie, w sposób właściwy wskazanym szkołom myślenia, współczesnych zjawisk i procesów wpływających na relacje między podmiotami kształtującymi politykę energetyczną na poziomie międzynarodowym. Służą temu dwa studia przypadku, z których pierwszy został poświęcony chińskiej strategii energetycznej na „Większym Bliskim Wschodzie” (neorealizm), drugi zaś - problemowi instytucjonalizacji polityki energetycznej Unii Europejskiej (neoliberalizm).

\section{BACK TO THE NEO-NEO DEBATE. TWO THEORETICAL PERSPECTIVES ON ENERGY SECURITY}

\begin{abstract}
The purpose of this article is to show the differences between the recognition of a neo-liberal and a neo-realist view in relation to the issue of energy security, but also to analyze, in a manner appropriate for designated schools of thought, contemporary phenomena and processes that affect relations between actors shaping the energy policy at the international level. To achieve this, the Author used two case studies. The first is dedicated to the Chinese energy strategy for the "Greater Middle East" (neo-realism), the second relates to issue of institutionalization of the EU energy policy (neo-liberalism).
\end{abstract}


